\title{
The Magnitude of Child Labour in Karnataka
}

\section{OPEN ACCESS}

Volume: 7

Issue: 3

Month: June

Year: 2019

ISSN: 2319-961X

Received: 16.03.2019

Accepted: 29.05.2019

Published: 01.06.2019

Citation:

Shivagami, G., and

T. Rajendra Prasad. "The

Magnitude of Child Labour

in Karnataka." Shanlax

International Journal of

Economics, vol. 7, no. 3,

2019, pp. 17-20.

DOI:

https://doi.org/10.34293/

economics.v7i3.388

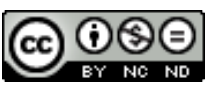

This work is licensed under a Creative

Commons Attribution-

NonCommercial-

NoDerivatives 4.0

International License

\section{G.Shivagami}

Research Scholar, Department of Economics

Bangalore University, Bangalore, Karnataka, India

\section{T.Rajendra Prasad}

Professor and Chairman, Department of Economics

Bangalore University, Bangalore, Karnataka, India

\section{Abstract}

In all societies irrespective of caste, race or area children occupied a very important position. A Child is the bud of future citizen of a country. Child labour is necessitated by economic compulsions of the parents and in many cases of the children. Widespread unemployment and underemployment among the adult poor are the main reason which has given rise to child labour. The major reason for hiring children viz., children's are easier to manage because they are less aware of rights, less complaining, more trust worthy, less troublesome and no problems of unions. Helmer Folkas, the chairman of National Child Labour Committee defined child labour as "any work of children that interferes with full physical development of their opportunity for a desirable minimum of education.

Keywords: Underemployment, National commission on Labour, Statutory Provisions, Unorganised Sector, Child workers, Magnitude, Industrial culture, Evil practice, Social Worker, Diseases, Migrant Children.

\section{Introduction}

Irrespective of caste in all societies, race or area children occupied a critical position. A Child is the bud of a future citizen of a country. Child labour is necessitated by economic compulsions of the parents and in many cases of the children. Unemployment and underemployment among the adult poor are the main reason which has given rise to child labour. The primary reason for hiring children viz., children's are easier to manage because they are less aware of rights, less complaining, more trustworthy, less troublesome, and no problems of unions. Helmer Folks, the chairman of the National Child Labour Committee, defined child labour as "any work of children that interferes with the full physical development of their opportunity for a desirable minimum of education.

The high rate of growth of population, large families with low income, are some of the reasons that breed child labour. Diverting the child from work means loss of revenue to the parents and an additional expenditure on education. However, small the economic benefits resulting from the child labour are generally high as it generates a profit, which is higher than what is consumed in the family. According to National Commission on Labour, the employment of children is non-existent in regulated industries. It persists in varying degree in the unorganised sector. Employment of child workers below the age is also reported to be continuing in rural areas where enforcement of statutory provisions is more complicated. It has been brought to notice that quite often it is the feeling of sympathy rather than a desire to exploit which wBFGmoyiE1 wor. 
Ironically enough, it is the feeling, which makes the inspecting officers take a lenient view of breaches of the legal provisions in this regard. In this context, it would also be relevant to quote the findings of the ILO report (1966) where 25 per cent of child labourers in the age group of 10 to 14 are working in developing countries. Many are employed illegally and in conditions that can kill them, while others grow up without education and are condemned to lifelong poverty. Child Labour is a human right question as well. More than 100 million children are working, and so many children are denied their fundamental rights. The ILO survey shows that the number of employed children is undoubtedly rising in many developing countries.

Over the years, however, global consciousness about the seriousness of the problem has been created. The Constitution of India also committed to the protection and promotion of welfare consideration over the economic ones. It is not surprising, therefore, that a series of committees and commissions have been appointed by the Government of India on the question of child labour as on labour conditions, in general, which give us insights into the problem and offer suggestions to alleviate this problem. The labour investigation committee in 1944, The National on Labour in 1966 and Guruprasadswamy Committee in 1986, deserves special mention in this regard.

\section{Objectives}

1. To analyse the prevalence of child labour in India.

2. To asses the magnitude of child labour in Karnataka.

\section{Prevalence of Child Labour in India}

Nearly 250 million children all over the world are estimated to be working for a living under pathetic conditions. The latest ILO report pushes child labour figures to an outstanding 250 million. Out of which about 120 million are working full time while 130 million work is part-time.

India is a house to 33 per cent of the child workforce, contributing 20 per cent to the Gross Domestic Product. India has the distinction of having the most significant child labour force in the world.
The government appointed a Commission on Labour Standards on International Trade states that child labour is increasing at the rate of 4 per cent in India.

Non-monetary and non-domestic work is usually found in the weak agrarian/rural economies. Children also work in the informal such as hotels, restaurants, wayside shops and establishments or as hawkers, newspaper sellers, coolie, shoe shine boys, vendors or as helpers in repair shops. Children also work as the bonded labourer and are pledged by their parents instead of debt. Accordingly to a study by UNICEF, there are more than a lakh child labour in the age group of five to fifteen in Mirzapur Carpet Industry, 50,000 in Firozabad, Glass Industry 50,000 in the Zari Industry in Lucknow, 20,000 in Aligarh Lock Industry and 30,000 in Brass Industry in Moradabad. In Tamilnadu and Kerala, 4.7 per cent and 13.2 per cent of the total labour force working in Cashewnut industry are children. Fireworks industry in Sivakasi in Tamilnadu employed 45,000 children.

The survey of the metropolitan cities makes shocking revelations, Mumbai has the most significant number of child labour. A recent report estimate that in Delhi about 60,000 children are employed in the dhabas, tea stalls, sweet shops and restaurants. In tea plantations of Assam and West Bengal child, labour is a common practice. In the modern period, with the advent of new industrial culture, the evil tradition of child labour has assumed an alarming proportion to attract the attention of social worker, philanthropists and social activists to its negative aspects. Various social organisations and leaders took serious note of this practice and made hue and cry. Consequently, it attracted the attention of the government, parliamentarians and social scientists that made several attempts to understand this problem from different angles.

\section{The Present Situation of Child Labour in India}

Children worked in dangerously polluted factories whose bricks, walls and scared with roof and there is an oppressive smell in the air. They work near furnaces, which has a temperature of 1400 centigrade; they handle dangerous chemicals like Arsenic and' Potassium. They work in glass-blowing units where the work exerts their lungs and creates diseases like T.B. Among the working children, 
many are the primary or significant wage earner in the family who always remain worried about feeding their dependents. The migrant child workers whose parents live far off city or village are generally in despair. Some work for 12 hours, including night shifts. When the industries (factories) are fully functional they are paid Rs. 500 per month; During the night shift, they hand over to their guardians who do not give them even a rupee per day for tea.

There are times when their body pains, minds fog, hearts cry, spirits bleed, but on the orders of the employer, they work 15 hours a day at a stretch. Several factories in Delhi, Tamilnadu, A.P, Maharashtra reveals that many child workers have sunken chests and skinny bone frames which give them a fragile look, they look like rag dolls, unwashed and scraggy. They wear coarse and poorly tailored clothes. Many have scabies on hands, arms and legs. The heads of a few are shorn probably because the skin on their skull has developed severe infections.

A large number of child workers are virtually confined in small rooms under inhuman conditions and in the most unhygienic surroundings. Most of these children come from poor households. They are either school dropouts or have not seen any school. They earn a very minimum wage and work in most: unsafe conditions. The hazardous conditions take their toll children to suffer from lung diseases-T.B, eye diseases, Asthma, Bronchitis and backaches. Some get injured in fire accidents. Many people become unemployable, even at the age of 20 . If injured or damaged, they are discarded mercilessly by their employers.

\section{Prevalence of Child Labour in Karnataka}

Karnataka has a relatively high incidence of child labour. According to the 1991 census, there are 9.76 lakh children working in the state including 8.18 lakh main and 1.58 marginal workers. The registration of India 1971 recorded nearly 10.74 million children as labourers. By 2011, the number of child labourers had increased to 15.59 million. A wide diversity is observed in the pace of and pattern of child labour in the different districts and regions in Karnataka. For the state as a whole, there has been a gradual but steady decline in both the male and female child workforce participation between 1961 and 1991.
Further, there is a significant variation in the pace of growth and reduction in the labour participation rates of children between districts. In about half of the States, districts, child labour has declined rapidly, while in the others, the pace of decline has been relatively low. The figures for the female child workers participation rate in the rural areas show a decrease between 1961 and 1971 in all the districts, but the later period, i.e. between 1971 and 1991, there has been a steady increase in the number of female child workers in a majority of the districts. This increase during the period 1981-91 has been particularly high in Bellary where it went up from 10.4 per cent in 1981 to 18.19 per cent in 1991 . Another unique feature is "Nowhere children" are children in the age group of 5-14 years who are neither in school nor at work. The data reveals that almost 50per cent of the female children and 40 per cent of the male children in Karnataka belong to this category. The percentage of this category is lower in urban areas as compared to the rural areas.

\section{Magnitude and Dimensions of Child Labour in Karnataka}

Although the incidence of child labour in Karnataka has been, comparatively low, the north Karnataka districts with high rates of poverty and backwardness showed a high prevalence of child labour. This suggests that child labour is induced more by economic reasons of poverty and indebtedness. Since, in a structurally unequal society, the access to economic mobility tends to lie in socio-cultural factors, the high incidence of child labour is found among the vulnerable castes like the SCs, the STs and Muslims. There has also been some growth of girl child labour. Agriculture and. Livestock rearing has of late emerged as critical sectors employing child labourers. Also, child labourers are also found in quarrying, construction, sericulture; hotels; shops, etc.

The SCLP is one of the most progressive and ambitious projects launched by the Government of Karnataka. It is even more liberal than the NCLP, in the sense that, it envisages residential bridge schools while the NCLP provides only Day schools. In terms of duration, it gives a six-year period for bridge schools. The primary objective of making 
Karnataka a child labour free-state is quite laudable. One understands that this is well it keeping with the tradition of progressive social policies of Karnataka.

\section{Conclusion}

To overcome the problem of child labour, the State must come out with concrete policy decisions to prevent child labour and to promote these children to schools. This by way of various activities by providing new social security benefits, street and home workers should be covered from social security. Hazardous activities are to be given full protection, and the children should not be employed under any circumstances. There is a need for individual courses to rehabilitate child labour. Separate University or Institute with the legal entity is required for working on child labour and developing them for national development. The University/Institute should conduct educational programmes, research and extension services on the issues relating to child labour concerning all their problems and to suggest remedial measures. The appropriate governments have to consider this issue with real spirit and implement the provisions effectively to eliminate child labour in various activities.

\section{References}

Bhat. P.N., Mani, A. and Ramesh. K. Child Labour Schooling and Fertility in Rural Karnataka, South India. ISEC, Bangalore, 1981.

Bhatt, K.N. Child Labour and Primary Education in India: An Overview. Deep and Keep Publication, New Delhi, 2001.

Bhavna Agarwal. A Study of Child Labour and its impact over household income. ABD Publication, New Delhi, 2007.

Burra Neera. "Child Labour in India: poverty, Exploitation and Vested Interest". Social Action, vol. 36, no. 3, 1986, pp. 241-263.

Burra Neera. Born to work-Child Labour in India. Oxford University Press, New Delhi, 1995.

Chandra Shekar, C.P. "Consequence of Abolition of Child Labour: An Indian Case study". The Journal of Peasant Studies, vol. 24, no. 3, 1997, pp. 137-139.

Chaudhry, D.P. "A Policy perspective on Child Labour in India with pervasive Gender and Urban Bias in School Education". IJLE vol. 40, no. 4, 1997, pp. 789-808.

Christopher, S. Benjamin and Kaboor, A. Child Labour and its correlates. Deep and Deep Publication, New Delhi, 2003.

\section{Author Details}

G.Shivagami, Research Scholar, Department of Economics, Bangalore University, Bangalore, Karnataka, India

T.Rajendra Prasad, Professor and Chairman, Department of Economics, Bangalore University, Bangalore, Karnataka, India. Email Id: trprasadbub@gmail.com 